\title{
Islamic Values in the Context of English Learning and Teaching
}

\author{
Zaitun'1), Siska Kusuma Wardani2) \\ 1), 2) Universitas Muhammadiyah Jakarta, South Tangerang, Banten, Indonesia \\ 1) zaitun.hateem@gmail.com, 2) moet_chika_girl@yahoo.com.
}

\begin{abstract}
The aim of this research is to describe the Islamic values in the process of teaching English. This research was conducted at SD Labschool FIP UMJ for about 3 months starting from June 2018 until August 2018. This study focuses on English teaching and learning process at 4 th graders. The study applied a qualitative descriptive research method which used observation and documents as the instruments in collecting the data. The writers observed both the school and 4th grade class and used the syllabus, lesson plan and English textbook as the documents. The analysis of the data showed that the Islamic values had been being well-built in the area of the school together with the school activities. While in the class observation the writer found that the Islamic values were not being applied yet in the process of teaching and learning English, besides, it was also found that syllabus, lesson plan, and textbook did not insert any Islamic values at all either in the content of the materials or in the teaching and learning activities. Thus this research study concludes that the Islamic values did not fully exist yet in the process of teaching English to the 4th graders of SD Labschool FIP UMJ.
\end{abstract}

Keywords: Islamic values, methods of teaching English, the process of English Citation APA Style: Zaitun, \& Wardani, S. K. (2018). Islamic Values in the Context of English Learning and Teaching. English Language in Focus (ELIF), 1(1), 71-80.

\section{INTRODUCTION}

$\mathrm{T}$ he fast growth of globalization nowadays also influences the world of education. Thus, the curriculum, teaching made, materials, learning process and media used in the teaching and learning process are required to be able to fulfill the needs of global world which should be more applicative and qualified. The learners are expected to be prepared in such a way so that they will be ready to compete in this technology era, so as in the subject of English.
As a universal language, English as a foreign language in Indonesia has been being taught since Kindergarten school even though in the national education curriculum this subject should be taught as one of the compulsory subjects taught in Primary school until university level. The goal of teaching this subject is that when the students graduate from university level at least they are ready to use this language both in spoken and written skills. Besides, the programs of Economics Society Association and Asian 
Free Trade Association (AFTA) launched by Indonesia are also gives added points to the needs of English learning.

The awareness of parents to the importance of English makes most of them to give their children extra hours to learn English; they send their children to a private or public English course. English which previously being considered as one of the most important subjects to support students' quality of competence then becomes a prestige subject. This creates an impression that if one student is excellent at English then this student is considered to have more 'value' than another student.

This phenomenon changes the mindset of the children in which they prefer to watch English cartoon movies, play imported games in their gadget, and or listen to English songs. The learning process of religion learning process seems gradually being left behind. Parents prefer to send their children to excellent schools or international schools which offer English as the instructional language used at schools than to let their children learn and stay at Islamic boarding schools. They would rather spend their money on expensive English courses rather than pay for Al-qur'an learning centers. The children will also be seen classier if they are able to deliver English speech than to be able to memorize surah from the Holy Qur'an (such as becoming a tahfiz; those who are able to memorize Al-qur'an).

The Islamic values should be built as early as possible to children so that the children will have the feelings of fear to God, be responsible to themselves and the society, be honest, humble and benefitted for their nations. Thus, it is a good thought if the learning of foreign language with all its culture given along with Islamic learning hence the students will not be good at foreign language but also be able to select and choose which cultures are appropriate with Islamic values and which are not.

According to Piaget, children in the ages between $7-12$ years old are at the best stage of cognitive development to be given the approaches of skills and memory information processes. The children make stable progress in the ability to process and keep the information. Children will also be able to absorb well and balanced anything taught to them if the stimulation given is also in a balanced portion. Building the Islamic values in the process of English learning will become something fun if the teacher is able to create a fun learning atmosphere with attractive and effective teaching strategies.

As one of the Elementary schools promoted as school model in the area of Cirendeu, SD Labschool FIP UMJ applies conventional English teaching method which is based on the demand of the curriculum. In Indonesia national education curriculum, the process of teaching religion and English is classified into two separate subjects. The third grade students (the highest grade in primary lower levels) which are taught English with the most difficult materials among the three grades in this lower level, the students are prepared to understand the learning process deeper so that they will master the basics of English when they move to the next grade (higher level). The integration of religious values in the process of English learning will be a good idea to be 
introduced to the students in the fourth grade (as the first grade in the higher level). This integrated learning process can be proposed as the new curriculum of English to be applied to 4th graders. Besides, Labschool FIP UMJ as the model school will also have added value to be imitated by other primary schools. Based on the background above, as the preliminary study, the writers are interested in research entitled: "Islamic Values in the Context of English Learning and Teaching". It is hoped that by this research, the Islamic values can be built especially in the teaching and learning of English.

\section{Islamic Values}

Bertens (2014) defines 'value' as something which attracts people to search for, something which is fun, something to be liked and wanted, or in short, value refers to something which is good. While Mulyana (2004) explains that value means a belief that makes someone does something based on his/her choices.

According to Kurniawati (2009), the main principle to build education which can produce qualified people should be based on the values from the Almighty God, Allah SWT. In education based on Islam, akhlak places an important and strategic position. Thus, the Islamic values can be defined as a concept and belief holding by humans in relation with several basic problems of Islam and used as the guidance in everyday's life both with the values come from Allah and or the values as the results of humans' interactions without against the shariah.
There are several main values in Islam, i.e. Aqidah, ibadah, akhlaq. According to Al-Banna (as cited in Shobron, 2011), aqidah value is a value of several problems which should be believed by heart, made comfort feelings, and give the faith with no doubtful. Ibadah value refers to everything loved and blessed by Allah SWT, such as words or actions, both seen or unseen, in order to praise Allah SWT and expect His rewards (Ritonga \& Tanjung, 1997). Ibadah is divided into 2; a) Specific ibadah or it is generally called Ibadah Mahdhah, such as: praying, giving, fasting and hajj, and b) General Ibadah or it is called Ibadah 'Ammah, such as: working, eating, drinking and sleeping in order to keep healthy so that the people can run their obligations as humans and get the blessings from Allah SWT.

According to Ilyas (2000), Akhlaq value is anything related to human's characters and will be appeared without thinking or considering other thing and having no external motivation. Akhlaq covers akhlaq to Allah SWT, to humans, and to nature.

\section{English as a Foreign Language Learning Process in Indonesia}

Brown (2000) argues that: "Language is a system of arbitrary conventionalized vocal, written, or gestural symbol that enables members of a given community to communicate intelligibly with one another" (p. 5). From this definition, Brown (2000) further proposes that 'language' can be defined as (a) systematic, (b) a set of separated symbols, (c) those symbols are dominated by vocals but could also 
be visual (d) the meanings of those symbols have been being adjusted with their references, (e) used as communication tool, (f) used as the topics in the society or culture, (g) essentially, language is used for humans even though it might not be limited for humans only, and (h) most languages used by humans have similar ways.

Based on those definitions above, English is Indonesia is taught as a foreign language. Indonesian people learn English because this language is a lingua franca and is used as an international language. The needs of the globalization era require Indonesian students to be prepared to compete in this world. Thus, the process of English learning designs by the government to be started since Elementary level until universities. As its basic goal, learning a language expects the learners to be able to use that language. Thus, the process of English learning in Indonesia has a certain design in which the students will be given chances to learn the whole language skills; listening, speaking, reading and writing, and to understand another aspect of this language, such as grammar, pragmatics, culture, etc.

Unfortunately, the process of this language learning is not in line with the religion's learning. English is taught separately as a part of the compulsory subject. However, even English is taught as a foreign language, its learning process is still based on the basic definition of learning. As Brown (2000) describes the followings:

a. Learning is an acquisition or "getting".

b. Learning is the retention of information or skill. c. Retention implies storage systems, memory, and cognitive organization.

d. Learning involves active, conscious focus on and acting upon events outside or inside the organism.

e. Learning is relatively permanent but subject to forgetting.

f. Learning involves some form of practice, perhaps reinforced practice.

g. Learning is a change in behavior.

\section{English Teaching Methods}

Teaching a subject should apply an appropriate teaching method so as with English teaching. This method should be based on several aspects such as the students' needs, materials, level of difficulties, subject discussions, facilities, etc. A teacher should be creative to use a method which is attractive and effective. One method can be modified with another method as long as it supports the learning objective (s).

There are several teaching methods in English, namely: GrammarTranslation, Direct methods, AudioLingual, Silent Way Method, Desuggestopedia methods and CLT (Communicative Language Teaching). Every method has its own characters and strengths. The teacher has the freedom to choose any method suitable with the students' needs since no one method is good or bad.

\section{RESEARCH METHODOLOGY}

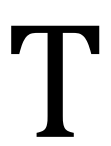
his study applied the qualitative descriptive method in which the objective of the investigation is to describe the Islamic values in the process of English teaching and learning to the 
4th graders of SD Labschool FIP UMJ, Cirendeu, Ciputat, Tangerang Selatan. Both English teachers and 4th grade students became the subjects and the informant in the study.

In collecting the data, the writers used documents and class observation checklist as the instruments. The writers used syllabus, lesson plan, and English textbook to whether in these documents Islamic values are also being inserted, while the writers observed both the school and 4th grade class which consisted of 22 students to directly get the pictures whether the teacher also integrated and or blended the Islamic values in the classrooms.

The observation checklist-sheet consisted of 13 closed-statements with the options of "YES' and "NO". If most of the results are "Yes" then it can be said that Islamic values are applied in the teaching and learning process and vice versa. The statements cover the whole process of one teaching session; preactivities, whilst activities, and postactivities. This observation check-list was made in two languages; Indonesian and English. The data were analyzed descriptively. The writers put each of their findings into the descriptive analysis.

\section{FINDING AND DISCUSSION}

$\mathrm{R}$ eferring to the objective of this research in which the writers aimed to find out the Islamic values in the process of teaching and learning English to the 4th graders of SD Labschool FIP UMJ, the analysis of the data revealed the following results:

\section{Observation}

The school observation was conducted on July 16th, 2018. In general, the building of Islamic values to the students at school is very good. Every morning, the students are welcomed by the teachers in the entry gate to build shaking-hands culture. The teachers greet every student with "Assalammu'alaikum". After school bell rings, the learning activity is firstly started by listening to Al-qur'an recitement by one of the teacher by using loud-speaker so all the school members can listen to it. After this, the teacher in every class will start the lesson on that day by firstly invites all students to recite short surrah. This activity is done every morning for about 10 to 15 minutes.

Beside these activities, the atmosphere of the school is very Islamic also. The way the teachers and the students dress-up represent how Moslems should perform in Islam. It can be seen from the area of the school also which full of hadist or short surrah displayed in the wall, wall-magazine, stairs, etc. to be read by all members of the schools. There are several characters of Allah written in Arabic language and English.

The class observation was conducted on July 26th, 2018. The writers used class observation sheet to be checked list. From this class observation, it was found out that the Islamic values have not been built yet along the teaching and learning process. The teacher only greeted the students with "Assalammu'alaikum" when entering the class and asked the students 
to recite basmallah and hamdalah before and after the class. While in all one teaching and learning session, there was no any single picture of Islamic values internalized in the activities.

\section{Documents}

In collecting the data, the writers used observation sheet, syllabus, lesson plan, and English text-book. The observation sheet consisted of 13 statements with two options; YES, and NO. The points in the statements covered 4 aspects of pre-activity, 6 aspects of whilst-activity, and 3 aspects of postactivity.

From the observation, it was resulted 6 responses to "YES", 6 responses to" NO", and 1 response which did not belong to either Yes or no. The results can be seen in the following table

Table 1. Observation Sheet of Teaching and Learning Process of the 4th Graders of SD Labschool FIP UMJ

\begin{tabular}{ccccc}
\hline No. & Description & No & Remarks \\
& Deskripsi & Yes & Tida & Keterangan \\
\hline
\end{tabular}

\begin{tabular}{|c|c|c|c|}
\hline \multicolumn{4}{|c|}{ A. Pre-teaching activities (Kegiatan sebelum mengajar) } \\
\hline 1. & $\begin{array}{l}\text { Teacher prepared the lesson plan with Islamic words } \\
\text { /terminology. Guru membuat silabi dengan } \\
\text { menyelipkan kata-kata/istilah agama Islam. }\end{array}$ & & $\begin{array}{l}\text { Guru tidak membawa } \\
\text { RPP sehingga tidak dapat } \\
\text { diamati }\end{array}$ \\
\hline 2. & $\begin{array}{l}\text { Teacher opened the class by saying Islamic greetings. } \\
\text { Guru membuka kelas dengan salam Islam } \\
\text { (Assalammualaikum). }\end{array}$ & $\sqrt{ }$ & $\begin{array}{l}\text { Guru menyapa kelas } \\
\text { dengan ucapan } \\
\text { "Assalammu'alaikum" }\end{array}$ \\
\hline 3. & $\begin{array}{l}\text { Teacher started the class by asking the students } \\
\text { reciting "basmallah". Guru memulai kelas dengan } \\
\text { mengajak siswa membaca basmalah. }\end{array}$ & $\sqrt{ }$ & \\
\hline 4. & $\begin{array}{l}\text { Teacher asked the students to pray before starting the } \\
\text { class. Guru meminta siswa berdoa sebelum memulai } \\
\text { kelas. }\end{array}$ & $\sqrt{ }$ & $\begin{array}{ll}\text { Guru memulai } & \text { kelas } \\
\text { dengan mangajak } & \text { siswa } \\
\text { bernyanyi bersama } & \end{array}$ \\
\hline
\end{tabular}

B. Whilst teaching activities (Kegiatan inti)

5. Teacher informed the students about the objectives of the lesson. Guru menyampaikan kepada siswa tentang tujuan dari pelajaran yang akan mereka pelajari

$\begin{array}{lr}\text { Guru } & \text { langsung } \\ \text { menjelaskan } & \text { tentang } \\ \text { materi pelajaran } & \text { hari itu, } \\ \text { yaitu "Greetings" } & \end{array}$

6. Teacher let the students know what is the benefits of the lesson in Islam perspectives. Guru memberitahukan siswa tentang manfaat dari materi tersebut dalam perspektif Islam.

7. Teacher discussed the lesson by giving the examples in Islamic contexts. Guru membahas pelajaran dengan memberikan contoh2 dalam konteks Islam.

8. The teacher used several Islamic words/terminology while teaching. Guru menggunakan beberapa katakata/istilah Islam ketika mengajar

Guru mengatakan bahwa salah satu contoh "Greetings" dalam Islam adalah ucapan "Assalammu'alaikum" Guru menyisipkan katakata: Assalammualaikum, Alhamdulillah, Allahuakbar

9. Teacher used appropriate and interesting media while teaching. Guru menggunakan media yang cocok dan menarik ketika mengajar 
10. Teacher used audio video as his/her teaching aid in teaching. Guru menggunakan audio video sebagai alat bantu mengajarnya

C. Post-teaching activities (Kegiatan setalah belajar mengajar)

11. Teacher summarized the lesson before ending the lesson. Guru menyimpulkan pelajaran sebelum mengakhiri pelajaran

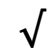

12. Teacher let the students to thank to Allah for their blessing day. Guru mengajak siswa untuk berterima kasih kepada Allah untuk keberkahan hari itu

13. Teacher dismissed the class by asking the students to pray/recite hamdalah. Guru menutup kelas dengan meminta siswa berdoa/mengucapkan hamdalah
Based on the observation sheet, it can be concluded that the Islamic values have not been applied fully in the teaching and learning process of English. The analysis of the syllabus showed that there were no Islamic values stated on the syllabus. The syllabus consists of the components of Basic Competence, Materials, Learning Activities, Competence Achievement Indicators, Assessment, Time Allotment and Learning Sources. It can be seen from the Standard Competence of each language skill that there is no Islamic values stated on this component, as well as in the learning activities.

The expected characters from the students are as follows: trustworthiness, respect, diligence, responsibility, and courage. The writers analyzed 6 lesson plans taken randomly from the academic year of $2017 / 2018$. The analysis of these lesson plans showed that there was no Islamic value at all stated on the components in the lesson plans. In the steps of learning activities; pre, whilst, and post, there were no Islamic values insertion, Standard Competence, Basic Competence, Achievement Indicators, and Learning Objectives described in the lesson plan did not show any of Islamic values insertion. The lesson plan also puts the expected characters owned by the students like in the syllabus stated above.

The English textbook used by the students is the one published by Yudhistira (2016), entitled: "Basic English for Elementary School Year 4", written by Sulaiman and Ament. The same like other English textbooks in general, this book does not insert any of Islamic values in its contents. The materials are presented like other English textbooks in general.

\section{School Observation}

Based on the findings it can be said that in general the Islamic atmosphere can be seen and felt at this school. Morning habits such as: shaking hands with teachers, greetings with Assalammualaikum, listening to holy Qur'an recitement and reciting short surrah show that the Islamic values are introduced to students of all grades/level. Besides, the way of the students (especially girls) and female teachers' dressed-up also showed how Islamic rules were built well. In the 
contrary, the classes' observation showed that Islamic values were not seen well in the teaching and learning process of English. The writers observed and did check-listing. The following table 2 shows the results of classes' observation:

Table 2. Classes Observation Check-list Results

\begin{tabular}{|c|c|c|c|c|}
\hline No. & $\begin{array}{c}\text { Description } \\
\text { Deskripsi }\end{array}$ & $\begin{array}{l}\text { Yes } \\
\text { Iya }\end{array}$ & $\begin{array}{l}\text { No } \\
\text { Tid } \\
a k\end{array}$ & $\begin{array}{c}\text { Remarks } \\
\text { Keterangan }\end{array}$ \\
\hline 1. & $\begin{array}{l}\text { Teacher prepared the lesson plan with Islamic } \\
\text { words /terminology. Guru membuat silabi } \\
\text { dengan menyelipkan kata-kata/istilah agama } \\
\text { Islam }\end{array}$ & & & $\begin{array}{l}\text { Guru tidak membawa } \\
\text { RPP sehingga tidak } \\
\text { dapat diamati }\end{array}$ \\
\hline 2. & $\begin{array}{l}\text { Teacher opened the class by saying Islamic } \\
\text { greetings. Guru membuka kelas dengan salam } \\
\text { Islam (Assalammualaikum) }\end{array}$ & $\sqrt{ }$ & & $\begin{array}{l}\text { Guru menyapa kelas } \\
\text { dengan ucapan } \\
\text { "Assalammu'alaikum" }\end{array}$ \\
\hline 3. & $\begin{array}{l}\text { Teacher started the class by asking the } \\
\text { students reciting "basmallah". Guru memulai } \\
\text { kelas dengan mengajak siswa membaca } \\
\text { basmalah }\end{array}$ & & $\sqrt{ }$ & \\
\hline 4. & $\begin{array}{l}\text { Teacher asked the students to pray before } \\
\text { starting the class. Guru meminta siswa berdoa } \\
\text { sebelum memulai kelas }\end{array}$ & & $\sqrt{ }$ & $\begin{array}{l}\text { Guru memulai kelas } \\
\text { dengan mangajak siswa } \\
\text { bernyanyi bersama }\end{array}$ \\
\hline
\end{tabular}

In the aspect number 1 , the teacher did not bring RPP while teaching then the writers did not put a check on this list. In the aspect number 2, the teacher said "Assalammua'alaikum" when opening the class, so that the Islamic value was checked to be "Yes". While in the $3^{\text {rd }}$ and $4^{\text {th }}$ aspects, the teacher did not invite the students to recite basmallah and or to pray, before starting the lessons, hence the checks were put into "No". Overall, the activities in this pre-teaching and learning process were dominated by "No", namely: "No" (2 aspects), while the other 2 aspects were "Yes", and 1 was either No or Yes.

Whilst-activities consisted of:

\begin{tabular}{|c|c|c|c|c|}
\hline No. & $\begin{array}{c}\text { Description } \\
\text { Deskripsi }\end{array}$ & $\begin{array}{l}\text { Yes } \\
\text { Iya }\end{array}$ & $\begin{array}{l}\text { No } \\
\text { Tid } \\
\text { ak }\end{array}$ & $\begin{array}{c}\text { Remarks } \\
\text { Keterangan }\end{array}$ \\
\hline 5. & $\begin{array}{l}\text { Teacher informed the students about the objectives of } \\
\text { the lesson. Guru menyampaikan kepada siswa tentang } \\
\text { tujuan dari pelajaran yang akan mereka pelajari }\end{array}$ & $\sqrt{ }$ & & $\begin{array}{l}\text { Guru langsung } \\
\text { menjelaskan tentang } \\
\text { materi pelajaran hari } \\
\text { itu, yaitu "Greetings" }\end{array}$ \\
\hline 6. & $\begin{array}{l}\text { Teacher let the students know what is the benefits of the } \\
\text { lesson in Islam perspectives. Guru memberitahukan } \\
\text { siswa tentang manfaat dari materi tersebut dalam } \\
\text { perspektif Islam }\end{array}$ & & $\sqrt{ }$ & \\
\hline 7. & $\begin{array}{l}\text { Teacher discussed the lesson by giving the examples in } \\
\text { Islamic contexts. Guru membahas pelajaran dengan } \\
\text { memberikan contoh2 dalam konteks Islam }\end{array}$ & $\sqrt{ }$ & & $\begin{array}{l}\text { Guru mengatakan } \\
\text { bahwa salah satu } \\
\text { contoh "Greetings" } \\
\text { dalam Islam adalah } \\
\text { ucapan "Assalammu'alaikum" } \\
\text { alam }\end{array}$ \\
\hline
\end{tabular}


8. The teacher used several Islamic words/terminology while teaching. Guru menggunakan beberapa katakata/istilah Islam ketika mengajar
Guru menyisipkan

kata-kata:

Assalammualaikum, Alhamdulillah, Allahuakbar

9. Teacher used appropriate and interesting media while teaching. Guru menggunakan media yang cocok dan menarik ketika mengajar

10. Teacher used audio video as his/her teaching aid in teaching. Guru menggunakan audio video sebagai alat bantu mengajarnya

In these activities, the assessment covered 6 aspects which were dominated by "Yes", i.e. in the aspects number $5,7,8$, 9 and 10. Aspect number 8 explained that teacher inserted several Islamic words such as Assalammu'alaikum,
Alhamdulillah, and Allahu'akbar. While aspect number 6 said that the teacher did not explain the benefit of the lesson seen from Islamic view. Thus, among those 6, 5 of the aspects were "Yes" and the other 1 was "No".

Post-teaching activities consisted of three aspects as follows:

\begin{tabular}{|c|c|c|c|c|}
\hline No. & $\begin{array}{l}\text { Description } \\
\text { Deskripsi }\end{array}$ & $\begin{array}{l}\text { Yes } \\
\text { Iya }\end{array}$ & $\begin{array}{c}\text { No } \\
\text { Tidak } \\
\end{array}$ & $\begin{array}{c}\text { Remarks } \\
\text { Keterangan } \\
\end{array}$ \\
\hline 11. & $\begin{array}{l}\text { Teacher summarized the lesson before ending the lesson. Guru } \\
\text { menyimpulkan pelajaran sebelum mengakhiri pelajaran }\end{array}$ & & $\sqrt{ }$ & \\
\hline 12. & $\begin{array}{l}\text { Teacher let the students to thank to Allah for their blessing day. } \\
\text { Guru mengajak siswa untuk berterima kasih kepada Allah untuk } \\
\text { keberkahan hari itu }\end{array}$ & & $\sqrt{ }$ & \\
\hline 13. & $\begin{array}{l}\text { Teacher dismissed the class by asking the students to pray/recite } \\
\text { hamdalah. Guru menutup kelas dengan meminta siswa } \\
\text { berdoa/mengucapkan hamdalah }\end{array}$ & & $\sqrt{ }$ & \\
\hline
\end{tabular}

In these post-activities, all checks went to "No" which showed that the teacher did not give any conclusion, the teacher did not invite the students to thank God for their lesson that day, and the teacher did not invite the students to recite hamdalah.

From those three stages of teaching and learning process, i.e. pre, whilst, and post, assessed from the observation, it can be concluded that the Islamic values have not applied that well by the teacher in the process of teaching English to $4^{\text {th }}$ graders of SD Labschool FIP UMJ.
The Assessment Aspects of Syllabus, Lesson Plan, and Text-book

The writers did not find any Islamic values being inserted in these three teaching and learning instruments. Even in syllabus and lesson plan, the writers found the point of "The expected characteristics" as follows: trustworthiness, respect, diligence, responsibility, and courage in which each of those characters is also explained by the Holy Qur'an and by Hadits, but in fact in the process of teaching, these characters were not delivered explicitly by the teacher. 


\section{CONCLUSION}

The analysis of the data puts several conclusions as follows:

1. The school observation revealed the conclusion that the Islamic values have been being applied very well at the school area starting from morning habits like greeting the students with "Assalammu'alaikum" and also from the way the teachers and the students dressing-up, etc.

2. The class observation showed that the teacher had not applied the Islamic values well in the three stages of teaching and learning activities, i.e. pre, whilst, and post-activities. The observation sheet which consisted of 13 statements were dominated by "No" check-lists in which 6 statements for "Yes", 6 statements for "No" and 1 other for neither Yes or No.

3. The syllabus which covered 4 language skills did not insert any single Islamic value in each component. It only put "The expected characteristics" as the goals of teaching while in fact in the real process; this point did not being applied explicitly.

4. As well as the syllabus, "the expected characteristics" were also being stated in the lesson plan, i.e. trustworthiness, respect, diligence, responsibility, and courage. As it was explained earlier in which these characteristics are stated both in holy Qur'an and Hadits, unfortunately, in the teaching and learning process, they were not seen being applied explicitly by the teacher, especially in English class.

5. The English textbook used was Basic English for Elementary School published by Yudhistira in 2016. The writers did not find any of Islamic values being inserted in this book either in the discussion of every chapter or in the exercises and passages presented.

6. Thus, from those conclusions, it can be concluded that the Islamic values were not being applied yet in the process of teaching and learning English to the $4^{\text {th }}$ graders of SD Labschool FIP UMJ.

\section{REFERENCES}

Bertens, K. (Kees). (2014). Etika. Jakarta: Gramedia Pustaka Utama.

Brown, H. D. (2000). Principles of Language Learning and Teaching. New York: Longman.

Ilyas, H. Y. (2000). Kuliah Aqidah Islam. Yogyakarta: Lembaga Pengkajian dan Pengamalan Islam.

Kurniawati, A. W. (2009). Pendidikan Nilai Berbasis Islam (Proses Penanaman Budi Pekerti dalam Bingkai Pendidikan Agama Islam). Malang : UIN Malang Skripsi.

Mulyana, R. (2004). Mengartikulasikan Pendidikan Nilai. Bandung: Alfabeta.

Ritonga, A. R., \& Tanjung, Z. (1997). Fiqih Ibadah. Jakarta: Gaya Media Pratama.

Shobron, S. (2011). Studi Islam. Surakarta: LPIK UMS. Bina Karya. 